Article

\title{
Can Rock-Rubble Groynes Support Similar Intertidal Ecological Communities to Natural Rocky Shores?
}

\author{
Paul Holloway ${ }^{1,2, *(\mathbb{D}) \text { and Richard Field }}{ }^{3}(\mathbb{D}$ \\ 1 Department of Geography, University College Cork, T12K8AF Cork, Ireland \\ 2 Environmental Research Institute, University College Cork, T23XE10 Cork, Ireland \\ 3 School of Geography, University of Nottingham, University Park, Nottingham NG7 2RD, UK; \\ Richard.Field@nottingham.ac.uk \\ * Correspondence: paul.holloway@ucc.ie
}

Received: 30 March 2020; Accepted: 24 April 2020; Published: 28 April 2020

\begin{abstract}
Despite the global implementation of rock-rubble groyne structures, there is limited research investigating their ecology, much less than for other artificial coastal structures. Here we compare the intertidal ecology of urban (or semi-urban) rock-rubble groynes and more rural natural rocky shores for three areas of the UK coastline. We collected richness and abundance data for 771 quadrats across three counties, finding a total of 81 species, with 48 species on the groynes and 71 species on the natural rocky shores. We performed three-way analysis of variance (ANOVA) on both richness and abundance data, running parallel analysis for rock and rock-pool habitats. We also performed detrended correspondence analysis on all species to identify patterns in community structure. On rock surfaces, we found similar richness and abundance across structures for algae, higher diversity and abundance for lichen and mobile animals on natural shores, and higher numbers of sessile animals on groynes. Rock-pool habitats were depauperate on groynes for all species groups except for sessile animals, relative to natural shores. Only a slight differentiation between groyne and natural shore communities was observed, while groynes supported higher abundances of some 'at risk' species than natural shores. Furthermore, groynes did not differ substantially from natural shores in terms of their presence and abundance of species not native to the area. We conclude that groynes host similar ecological communities to those found on natural shores, but differences do exist, particularly with respect to rock-pool habitats.
\end{abstract}

Keywords: biodiversity; non-native species; protected species; range expansion; species distributions

\section{Introduction}

Climate change and anthropogenic pressures have fragmented and restricted the distribution of many species worldwide, with significant shifts documented in a vast array of ecological communities [1-4]. In coastal ecosystems, numerous studies have reported a decline in biodiversity [5-12]. For example, Sorte et al. [9] noted a $60 \%$ decline in the abundance of the blue mussel Mytilus edulis over the past 40 years along the coastline of Eastern USA and linked this decline with that of several other species within the intertidal community. With at least a billion people expected to live within the lower-elevation coastal zone by 2060 [13] and up to 12.5 million $\mathrm{km}^{2}$ of natural habitat potentially replaced by $2030[14,15]$, there persists a need to identify how novel artificial habitats impact coastal ecology.

Introducing hard-engineering structures can negate many of the perceived negative geomorphological and economic impacts of coastal erosion, particularly in urban environs; however, these structures can have significant implications for the configuration of intertidal habitats and biodiversity [16-18]. Studies have predominantly focused on determining whether the communities 
found across analogous natural shores (largely situated in rural areas) versus artificial structures (largely situated in urban or semi-urban areas) are comparable [18]. The consensus so far is that there is higher diversity on natural shores than analogous artificial rocky sea defences [19-26]. However, investigations have not been conclusive, identifying differences across tidal heights [27] and taxa [28,29], while others have found a strong similarity between structures [30,31].

Rock-rubble groynes are commonly implemented hard-engineering structures that run perpendicular to the shoreline, intercepting longshore transport of sediment. The intertidal habitat of these artificial structures offers a new rocky habitat that is typically located in predominantly sandy shorelines; however, there are very few studies investigating the ecology of rock-rubble groynes. Studies by Pinn and Rodgers [32] of a natural rocky shore and by Pinn et al. [21] of rock-rubble groynes in Dorset, UK, found higher species richness and abundances of most species on the natural rocky shore at Kimmeridge Bay than on the rock-rubble groynes at the nearby Sandbanks Peninsula. However, the ecological comparison between the structures was not the predominant focus of either study, and there was no statistical analysis beyond the simple comparisons of biodiversity. Similarly, in a study comparing the ecology of eight artificial structures (five of which were groynes) and eight natural rocky-shores in the UK, Firth et al. [23] found higher mean species richness on the natural rocky shores than the artificial structures, with no species unique to the artificial structures. Firth et al. [23] also compared habitats, finding that rock pools supported greater species richness than rock habitats, irrespective of structure. This contrasts with the results of Pinn et al. [21], who found more species on exposed rock than in the pools on the groynes at Sandbanks. The findings of these studies suggest that, while groynes support a lower level of biodiversity than their natural counterparts, they could provide a refuge for intertidal communities found on rocky shores that are under pressure from increasing urbanisation.

Conversely, a major criticism of locating hard-bottom artificial structures in soft-bottom areas of coastline is that they can contribute to the decline of barriers (impassable areas of soft-bottom coastline) which isolate distinct regions of rocky shores: removing barriers may enable the dispersal of larvae and propagules of invasive species beyond their natural limits [33-35]. For example, Airoldi et al. [35] found that non-indigenous species were 2-3 times more abundant on artificial structures in part of the North Adriatic Sea, and several other studies have also found artificial structures to support non-indigenous species [36-39]. These studies conclude that there are more non-indigenous species on artificial structures than on nearby rocky shores because they act as points of invasion for many of the non-indigenous taxa. Because of these points of invasion and the resulting creation of stepping-stone dispersal corridors, hard-bottomed artificial structures may pose a serious concern for biodiversity [40].

The UK coastline is one of the most highly human-impacted ecosystems in the world [41]. With the projected coastal urbanisation and climatic changes, there is a pressing need to identify how intertidal communities differ between rock-rubble groynes in urban environs and analogous natural rocky shores in rural areas. Theoretically, rock-rubble groynes provide a conservation dilemma. They offer an opportunity for the presence of novel rock habitat that could have beneficial implications for populations of under-pressure intertidal species predominantly in highly-impacted urban environments, yet they increase connectivity between isolated rocky shores, which may support populations of native species or increase the potential for non-native species invasion, or both. With only two studies [21,23] having compared the ecology of natural rocky shores with those of rock-rubble groynes (one of these only as an in-passing comment), and with contrasting results found in a single study area (Sandbanks peninsula, Dorset), the questions of whether rock-rubble groynes support ecological communities similar to natural rocky shores, and whether they represent a conservation opportunity or threat, remain open. Furthermore, we still lack basic knowledge of how diverse and abundant the rock-rubble groyne communities are.

Here we compare the ecological communities of both exposed rock and rock pools between rock-rubble groynes and nearby rocky shores, using a paired sampling design repeated in three locations around the coast of England. We focus on four main questions: do urban rock-rubble groynes 
and nearby rural rocky shores (hereafter we refer to the two collectively as rocky 'structure types') differ in terms of (1) their species richness and (2) their species' abundances? (3) Are there specific communities found on one of the structure types but not the other? (4) Do the rocky structure types differ in terms of presence and abundance of species not native to the area (considering native status at both a country and a within-country level)? In addressing these questions, we investigate the role of rock pools as well as rock surfaces and investigate all macro-organisms found, doing parallel analyses for algae, lichens, sessile animals and mobile animals.

\section{Materials and Methods}

\subsection{Study Area and Data Collection}

We selected three stretches of the English coastline that each contained a rural natural rocky shore and urban (or semi-urban) rock-rubble groynes in reasonably close proximity to each other (Figure 1, Table SI1). This gave us three pairs of study sites (Supplementary Information 1), which we sampled in summer 2008. In each site with artificial structures, we randomly selected three rock-rubble groynes of the same age to survey (Table SI1). To control for variations in tidal shore height, we separated each structure into low-, mid- and high-shore sections (we call this variable 'level') based on the mean low- and high-water spring tides. We did not identify tidal height boundaries by the limits of organisms, as often recommended [42] because both physical and biological components influence the zonation of organisms [43], meaning there is the possibility to introduce considerable cross-site error.

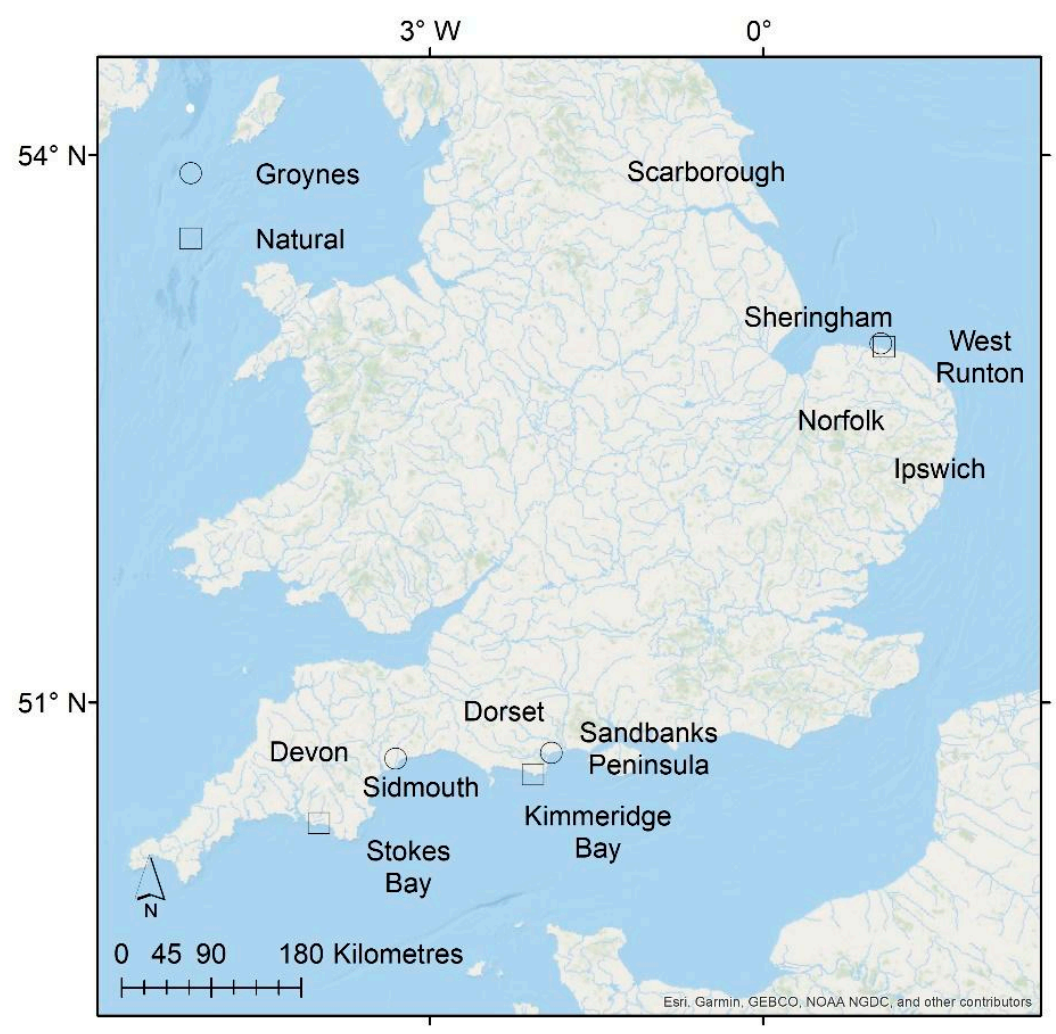

Figure 1. Location of study sites around the coast of England. Devon, Dorset, and Norfolk are counties. Ipswich and Scarborough are locations mentioned in the text.

We used a stratified random sampling technique. With 2 structure types (natural, groyne), 3 counties (Devon, Dorset, Norfolk), 3 replicates of each structure type in each county and 3 levels (high, mid, low) per structure, we had 54 sampling sections in total. Due to the uncertain influence of aspect and exposure on intertidal biological assemblages [21,44], we only surveyed the side of the groynes that did not face the dominant longshore current (therefore sheltered from wave action). Each 
section of the sampling area was divided up into $0.5 \mathrm{~m}^{2}$ squares to reduce the chance of recording the same individual twice and selected using a random number generator [42]. On open rock surfaces, we randomly located 12 quadrats in each sampling section, each of $0.25 \mathrm{~m} \times 0.25 \mathrm{~m}$, making 648 rock-surface quadrats in total, and where necessary moved quadrats to avoid sampling very deep crevices or between boulders to allow for consistent surface areas [29]. In each sampling section, we also selected three rock pools (of similar size to the quadrats across structures) in the same way, or all rock pools in the section if fewer than four were present. Ten of the sampling sections (nine of them on groynes) contained no rock pools at all. Overall, we placed quadrats in 123 rock pools: 74 on natural rocky shores and 49 on groynes. In addition, we counted the total number of rock pools present on each entire groyne or equivalent area of natural shore. We did not measure the depth and perimeter of rock pools as is sometimes recommended [42] due to the time constraints associated with the survey, and we acknowledge the limitations of this approach on the analysis in the discussion.

We used a non-destructive sampling method, recording species as present if observed within the quadrat. We recorded species richness as the total number of species in each quadrat. For mobile organisms, we recorded abundance as the count of individuals in each quadrat or pool, and for lichens, algae and sessile animals, we recorded abundance as percentage cover using a grid. We grouped the twelve rock quadrats in each sampling section into four sets of three neighbouring quadrats and grouped the three rock-pool quadrats into one set of three rock-pool quadrats (where we had sufficient numbers), with each data value being the arithmetic mean of these quadrats (e.g. the mean number of animal species A across three quadrats). Thus, each unit in the analysis represented a small section of habitat sampled using three quadrats, rather than a single very small quadrat. This was to allow a better representation of the local community in each unit of analysis and to reduce any variation and uncertainty associated with slight differences in pool volume and surface area due to the uneven surface of the study areas. Overall, the data analysed included 216 rock surface samples and 46 rock pool samples.

\subsection{Data Analysis}

We used a three-way analysis of variance (ANOVA) to explore the differences between rock-rubble groynes and natural rocky shores (the 'structure type' explanatory variable). We also included the following factors to account for their expected influence: 'county' (Devon, Dorset, Norfolk—reflecting the pairing of the sites) and [tidal] 'level' (low, mid, high). We used Levene's test to examine the assumption of homogeneity of variance, and we visually examined the model residuals for patterning and tested them for normality using Kolmogorov-Smirnov tests. These diagnostics caused us to square-root transform the response variable in the analyses of species' abundances. We ran parallel analyses for rock and pool habitats. We then used detrended correspondence analysis (DCA) to identify ecological communities and significant environmental centroids within the full species dataset among sites which had species recorded within them. DCA reveals the dispersion of points in ordination space, which reflects species abundances within sampling sites [45]. Due to the high frequency of rare species in pools, analysis was undertaken for both rock and pool habitats together, but rare species were not down-weighted as sometimes suggested [46] due to minimal differences in the results when both habitats (rock and pool) were considered together and the importance of the rarer species to ecological communities on natural shores. We chose DCA over other ordination analyses due to the long gradient lengths [47] and the fact that DCA is based on the underlying unimodal model of species distributions [48] - a key foundation of our research questions. We explored the implementation of another method (nonmetric multidimensional scaling: nMDS), but found that the long computation time, coupled with the lack of model convergence and the impact of rare species, made manually exploring model options and subsequent interpretation of the results overly complex. Moreover, results from the nMDS were largely congruent with those of DCA, with the exception of the extreme impact of rare Idotea and Gammarus spp (results not shown). Environmental factors were passively projected on the ordination plot. All analysis was implemented in the open-source software R 3.6.2 [49], 
with the DCA implemented using the vegan package [46]; see Supplementary Information 2 for data and Supplementary Information 3 for $R$ code.

We compared recorded presences in our study with species distribution maps from Gibson et al. [50] and the Marine Life Information Network (MarLIN; [51]) to determine whether we recorded species beyond their distributions, as judged by the two sources. Gibson et al. [50] provide a generalised range of each species, while MarLIN [51] maps are generated from published species records and verified sightings. We chose these sources to correspond with the period of data collection, rather than the most up-to-date distributional data.

\section{Results}

\subsection{Species Richness and Abundance}

We recorded 81 species in total: 27 algae, 6 lichens, 11 sessile animals and 37 mobile animals (Supplementary Information 4). We found 48 species on the groynes and 71 species on the natural rocky shores. Species richness was higher on the natural rocky shores than on the groynes; however, this varied by species group and habitat type (Figure 2a,b). On rock surfaces, species richness on natural shores was significantly higher than that for groynes (Figure 2a, Table 1); however, when species groups were disaggregated, the difference was not significant for algae and there were significantly more sessile animal species on groynes. In the rock pools, species richness was substantially higher on natural rocky shores than groynes for all species groups except sessile animals (no significant difference) and lichens (none recorded in pools) (Figure 2b, Table 1). Indeed, the rock pool habitat represents a key difference between the groynes and the natural rocky shores. Of the 81 species we recorded, 66 were present in rock pools, including 21 only recorded in rock pools. Of these 21 , twelve were only in natural rock pools ( 5 algae, 7 mobile animals), three only in pools on groynes (all were mobile animals) and six in both ( 5 mobile animals, 1 sessile animal). Species richness varied significantly between counties and across tidal levels, and these factors interacted with structure type to varying degrees to affect the magnitude of species richness difference between groynes and natural rocky shores (Figure 3, Table 1).

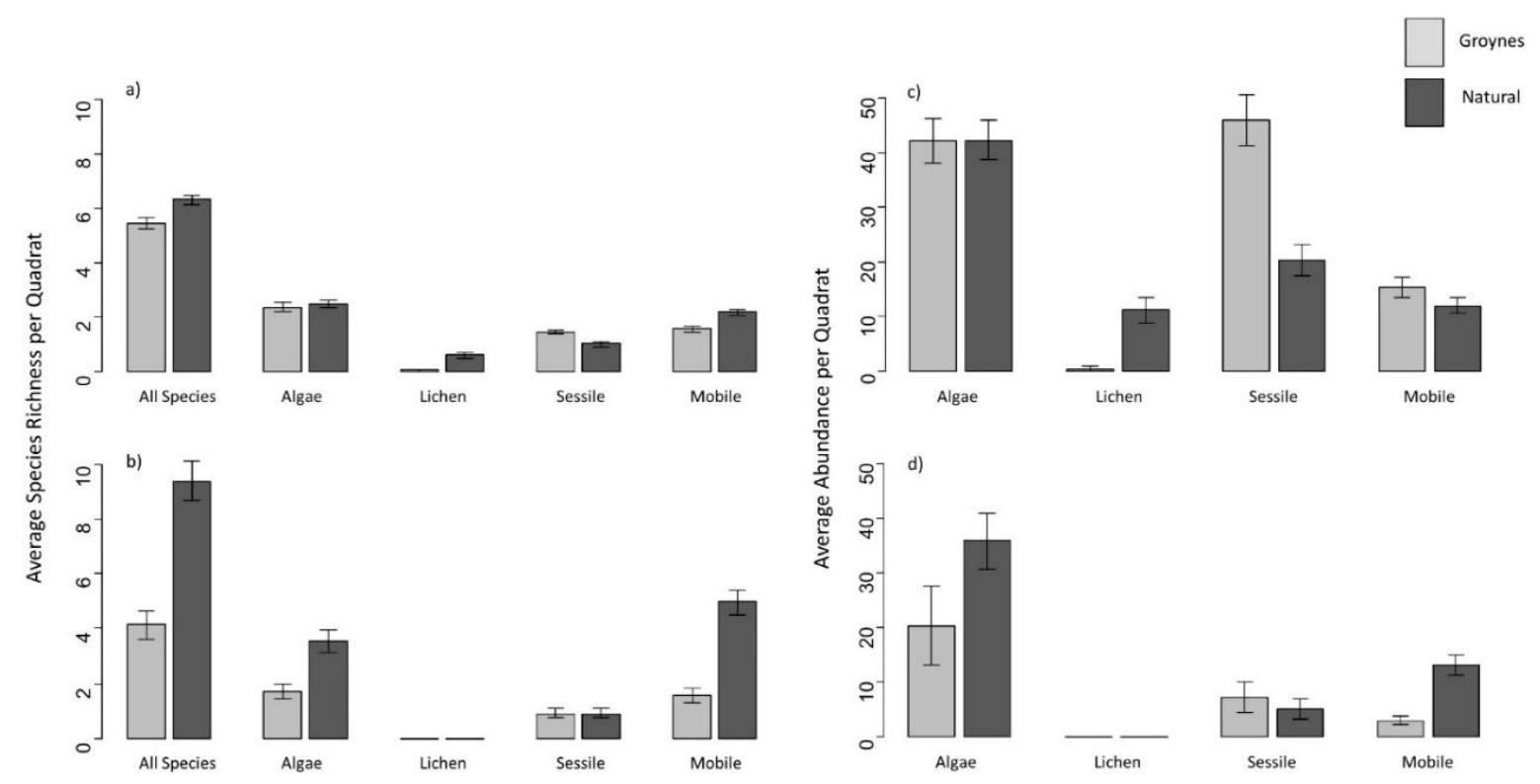

Figure 2. Comparison of species richness on (a) rock surfaces and (b) rock pools, and of species' abundance on (c) rock surface and (d) rock pools, between rock-rubble groynes and natural rocky shores. Error bars represent 1 standard error of the mean. Abundance for algae, lichen and sessile animals is shown as percentage cover, and for mobile animals is shown as the total count. 
Table 1. Results of the analysis of variance (ANOVA) testing the effects of County, Type, and Level, on average species richness per quadrat, averaged over a set of up to three quadrats. 'Type' is the rocky structure type (natural vs. artificial). 'Level' is the tidal level (low, medium, high). 'County' refers to the three stretches of coastline (Devon, Dorset, Norfolk). ${ }^{* *} p<0.01,{ }^{*} p<0.05$.

\begin{tabular}{|c|c|c|c|c|c|c|c|c|}
\hline $\begin{array}{l}\text { Response } \\
\text { Variable }\end{array}$ & & Type & Level & County & $\begin{array}{l}\text { Type* } \\
\text { Level }\end{array}$ & $\begin{array}{l}\text { Type * } \\
\text { County }\end{array}$ & $\begin{array}{l}\text { Level * } \\
\text { County }\end{array}$ & $\begin{array}{l}\text { Type * Level } \\
{ }^{*} \text { County }\end{array}$ \\
\hline & $\mathrm{df}:$ & 1 & 2 & 2 & 2 & 2 & 4 & 4 \\
\hline total: Rock & $\mathrm{F}:$ & $14.76^{* *}$ & $50.85^{* *}$ & $9.18^{* *}$ & $5.09 * *$ & 1.00 & $3.48 * *$ & $4.88^{* *}$ \\
\hline algae: Rock & $\mathrm{F}:$ & 0.56 & $37.45^{* *}$ & $41.17^{* *}$ & $4.76^{* *}$ & $8.19 * *$ & $3.26 *$ & 2.12 \\
\hline lichen: Rock & $\mathrm{F}:$ & $58.89 * *$ & $50.06^{* *}$ & $13.79^{* *}$ & $33.92 * *$ & $9.32 * *$ & $8.49 * *$ & $5.07 * *$ \\
\hline sessile: Rock & $\mathrm{F}:$ & $17.75^{* *}$ & $36.02 * *$ & $12.45^{* *}$ & $3.05 *$ & 0.83 & $7.12 * *$ & $7.31 * *$ \\
\hline mobile: Rock & F: & $24.27^{* *}$ & $14.71^{* *}$ & $22.98^{* *}$ & $7.18^{* *}$ & $8.24^{* *}$ & $6.11 * *$ & $9.15^{* *}$ \\
\hline total: Pool & $\mathrm{F}:$ & $58.74 * *$ & $5.55 * *$ & 2.72 & 1.40 & 1.46 & $5.46 * *$ & 2.68 \\
\hline algae: Pool & $\mathrm{F}:$ & $22.45^{* *}$ & $3.96 *$ & $3.85 *$ & 3.23 & $7.20 * *$ & $4.03 *$ & 0.22 \\
\hline sessile: Pool & F: & 0.007 & $8.90 * *$ & 3.15 & 1.10 & $5.48 *$ & 0.45 & 1.77 \\
\hline mobile: Pool & F: & $56.97 * *$ & 0.81 & 2.52 & 0.54 & 0.41 & $3.23 *$ & $3.21 *$ \\
\hline
\end{tabular}

a) Norfolk
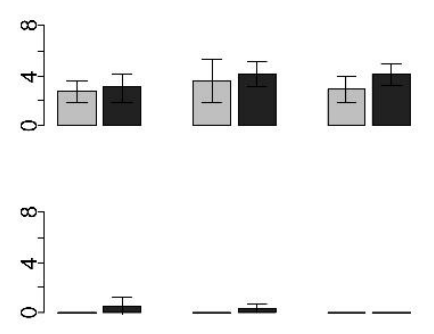

of

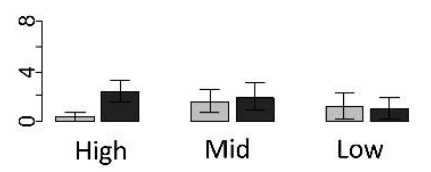

b)
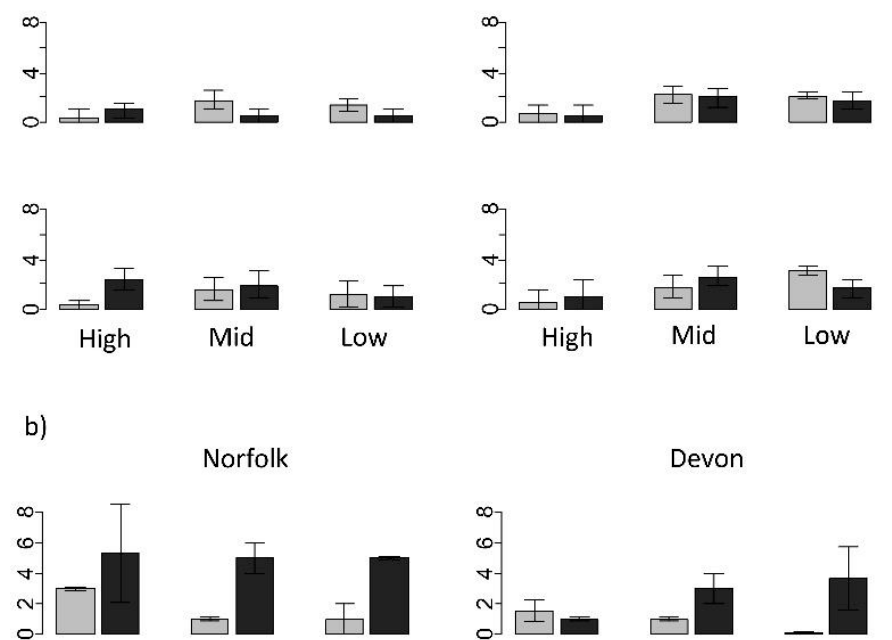

Devon

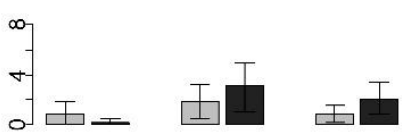<smiles>C1=CCCC1</smiles><smiles>C1=CCC1</smiles>

Devon

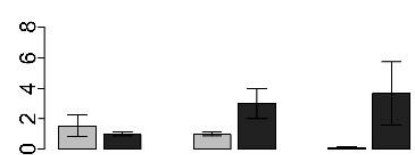

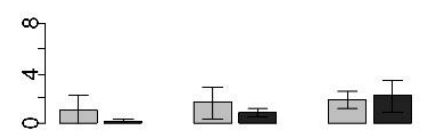

Sessile
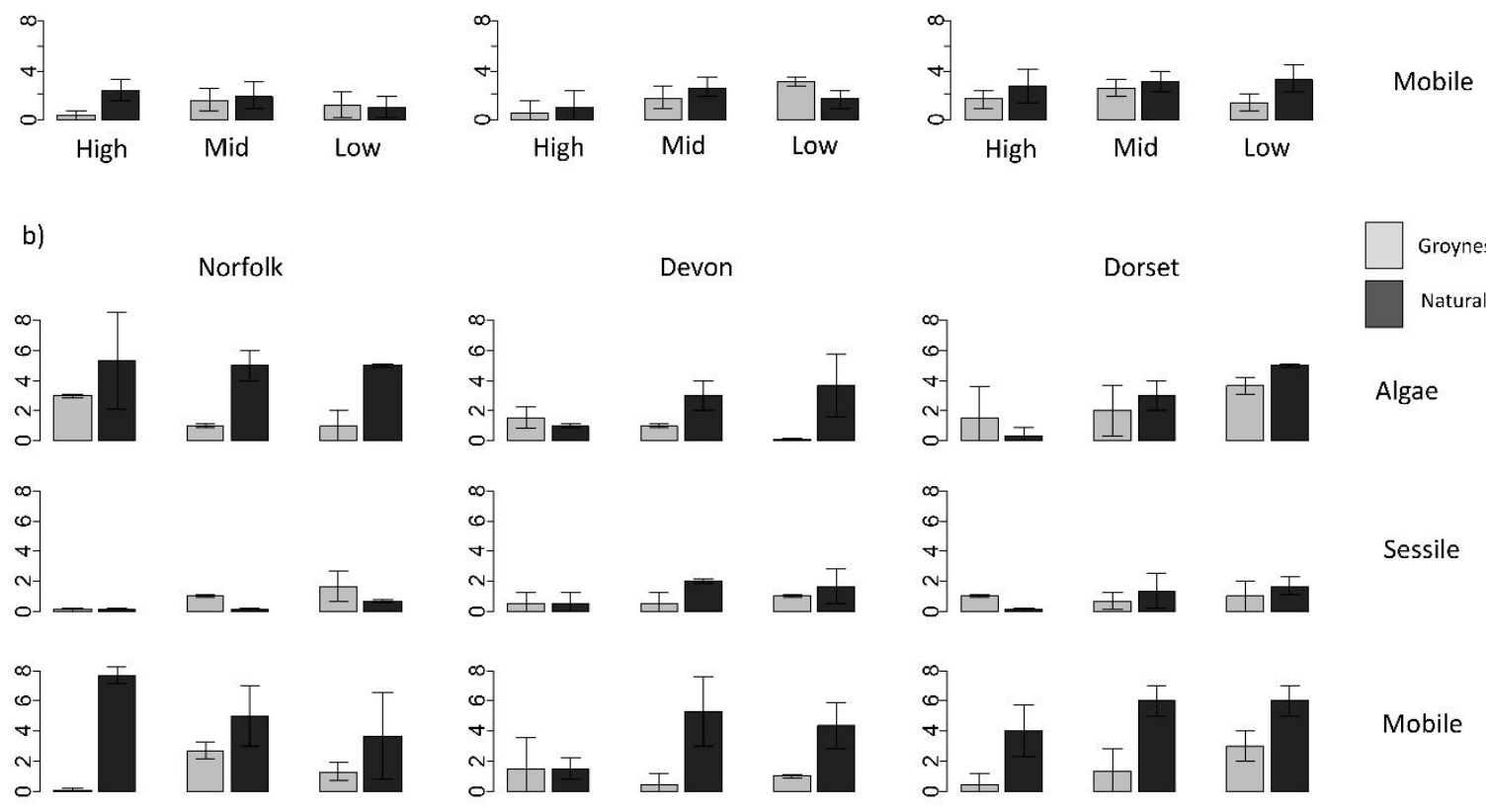

High

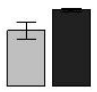

Algae

Dorset

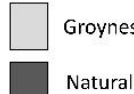

Natural

Sessile
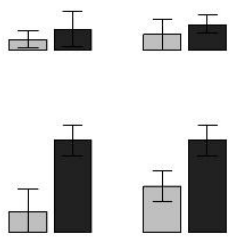

Mobile

roynes

atural

Algae

ichen

\section{ile}

Mid Low

Figure 3. Comparison of species richness on (a) rock surfaces and (b) rock pools, among tidal levels and counties. Error bars represent 1 standard error of the mean. 
Findings were different when we considered abundance (Figure 2c,d, Table 2). We found no significant differences in abundance between structure types for algae or mobile animals in the rock habitat, although in pools the abundances were significantly higher on natural shores. Again, we found a significantly higher abundance of sessile animals on the rock habitat of groynes than natural shores, although this pattern was not significant for pool habitats. Abundance also depended strongly on the tidal level, county, and habitat studied (Supplementary Information 5). For example, in Devon, algal abundances on natural shores increased towards low tide on the rock habitat while it decreased towards low tide in pool habitats. Differences also existed across structures, with algal abundances in Norfolk decreasing towards low tide on groynes in pools but increasing on natural structures in pools (Supplementary Information 5). Abundance differences between structures were notable for mobile species, particularly in rock pools $(\mathrm{F}=56.97$; Table 2$)$. The abundance of mobile animals was generally greater on natural rocky shores, with this difference prominent in Dorset. However, we observed nearly the opposite pattern in Devon, with abundances of mobile animals not significantly different across structures in pools and on rocks at most tidal levels, and abundance higher at low tide for groynes than natural shores.

Table 2. Results of the analysis of variance (ANOVA) testing the effects of County, Type, and Level, on average species abundance per quadrat, averaged over a set of up to three quadrats. 'Type' is the rocky structure type (natural vs. artificial). 'Level' is the tidal level (low, medium, high). 'County' refers to the three stretches of coastline (Devon, Dorset, Norfolk). ${ }^{* *} p<0.01,{ }^{*} p<0.05$.

\begin{tabular}{|c|c|c|c|c|c|c|c|c|}
\hline Response Variable & & Type & Level & County & $\begin{array}{l}\text { Type * } \\
\text { Level }\end{array}$ & $\begin{array}{l}\text { Type* } \\
\text { County }\end{array}$ & $\begin{array}{l}\text { Level }{ }^{*} \\
\text { County }\end{array}$ & $\begin{array}{c}\text { Type * Level } \\
* \text { County }\end{array}$ \\
\hline & df: & 1 & 2 & 2 & 2 & 2 & 4 & 4 \\
\hline algae: Rock (sqrt) & $\mathrm{F}:$ & 0.02 & $11.37^{* *}$ & $31.90 * *$ & 10.32 ** & $12.47 * *$ & $3.13 *$ & $3.81 * *$ \\
\hline lichen: Rock (sqrt) & $\mathrm{F}:$ & $57.52 * *$ & $47.30 * *$ & 12.74 ** & 31.16 ** & $8.53^{* *}$ & $8.90 * *$ & $5.53 * *$ \\
\hline sessile: Rock (sqrt) & $\mathrm{F}:$ & $52.21 * *$ & 79.60 ** & $15.27 * *$ & $20.44 * *$ & $15.65^{* *}$ & $3.53 * *$ & $14.62 * *$ \\
\hline mobile: Rock (sqrt) & $\mathrm{F}:$ & 1.05 & $17.13^{* *}$ & $53.42 * *$ & $16.90 * *$ & $8.60 * *$ & $8.59 * *$ & 2.16 \\
\hline algae: Pool (sqrt) & $\mathrm{F}:$ & $11.25^{* *}$ & 1.88 & 0.01 & $8.03 * *$ & $5.56^{* *}$ & $3.16^{*}$ & 1.60 \\
\hline sessile: Pool (sqrt) & $\mathrm{F}:$ & 0.97 & $7.37 * *$ & $5.42 *$ & 1.51 & $10.80 * *$ & 0.29 & $3.22 *$ \\
\hline mobile: Pool (sqrt) & $\mathrm{F}:$ & $54.02 * *$ & 2.49 & $3.80 *$ & $3.98 *$ & $9.13 * *$ & 2.67 & 1.66 \\
\hline
\end{tabular}

\subsection{Species- and Community-Level Analysis}

Of the 21 species found only in rock pools, most were mobile organisms. Of these mobile species, Idotea granulosa, Gibbula cineraria and Lacuna vincta could potentially survive outside of pools; however, all are sensitive to rapid desiccation or feed on algal species that require water. The other mobile species were either shrimp or fish, which could not survive on open rock. The five species of algae that were only found in rock pools all require sublittoral habitats, except Gelidium pusillum, and were all found only on natural shores. The species found only in pools on groynes were generalist species, which were widely distributed and associated with sandy habitats, such as the brown shrimp Crangon crangon. Species only found on rock surfaces on groynes were the Greenleaf worm Eulalia viridis and the Dahlia anemone Urticina felina, with each only identified at one site: Sidmouth and Sandbanks, respectively. We identified only one Dahlia anemone at Sandbanks, while we found Greenleaf worms (in high abundances) in every low tide quadrat of one groyne at Sidmouth. Both species are habitat-specific, with the anemone requiring crevices and water, and the Greenleaf worm requiring mussel beds. Our dataset contains three species that are of conservation concern (Table 3), with the dog whelk Nucella lapillus occurring in higher abundances on the groynes and the other two at slightly higher abundances on the natural rocky shores.

DCA (Figure 4, Table SI4) revealed two main gradients in the differentiation of intertidal species composition. The first axis (DCA1) appears to be influenced by type and county and contains the most spread [eigenvalue 0.8114], while the second axis (DCA2) appears to be influenced by tidal level, with less spread [eigenvalue 0.5751]. Distinct communities were observable on the ordination plot. For example, communities found high on axis 1 are dominated by samples from natural shores at 
high tide and consist of predominantly lichens. Lichens favour areas of high stress and disturbance and are only found on bedrock or boulders [52], so were expected to be found on rocks in the high shore; however, their absence on groynes is notable and is perhaps related to the slow growth rates observed in marine lichens [53]. Species found low on axis 1 are those that occur on groynes in high abundance (e.g., Northern Acorn Barnacle Semibalanus balanoides, Ulva intestinalis) across all sites. Species found at either end of axis 2 include sponges and algae sensitive to desiccation at the lower end and fish and anemones at the higher end. These results suggest that distinct communities of species that are sensitive to desiccation exist at all tidal levels. Overall, this analysis suggested only a slight differentiation between communities on groynes versus natural rocky shores, part of which reflects the absence of lichens on the relatively new surfaces of the groynes.

Table 3. Total abundance of the three species of conservation concern. For Padina pavonica, the units of abundance are percentage cover averaged across a set of up to three quadrats; for Nucella lapillus and Pomatoschistus minutus they are the total number of individuals per quadrat averaged over a set of up to three quadrats (see Methods). Conservation conventions and legislation: UK Biodiversity Action Plan (UKBAP), the Convention for the Protection of the Marine Environment of the North-East Atlantic (OSPAR), and Bern Convention is the Bern Convention on the Conservation of European Wildlife and Natural Habitats.

\begin{tabular}{ccccc}
\hline & & \multicolumn{2}{c}{ Species } \\
\cline { 3 - 5 } & & $\begin{array}{c}\text { Padina } \\
\text { Pavonica }\end{array}$ & $\begin{array}{c}\text { Nucella } \\
\text { Lapillus }\end{array}$ & $\begin{array}{c}\text { Pomatoschistus } \\
\text { Minutus }\end{array}$ \\
\cline { 3 - 5 } Marine and Conservation Conventions and Legislation & UK BAP & OSPAR & Bern Convention \\
\hline Structure Type & Habitat & & & \\
\hline Groyne & Rock & $X$ & 102.3 & $X$ \\
Groyne & Pool & $X$ & 26.5 & 0.3 \\
Natural & Rock & $X$ & 1.0 & $X$ \\
Natural & Pool & 14.3 & 1.0 & 11.7 \\
\hline
\end{tabular}

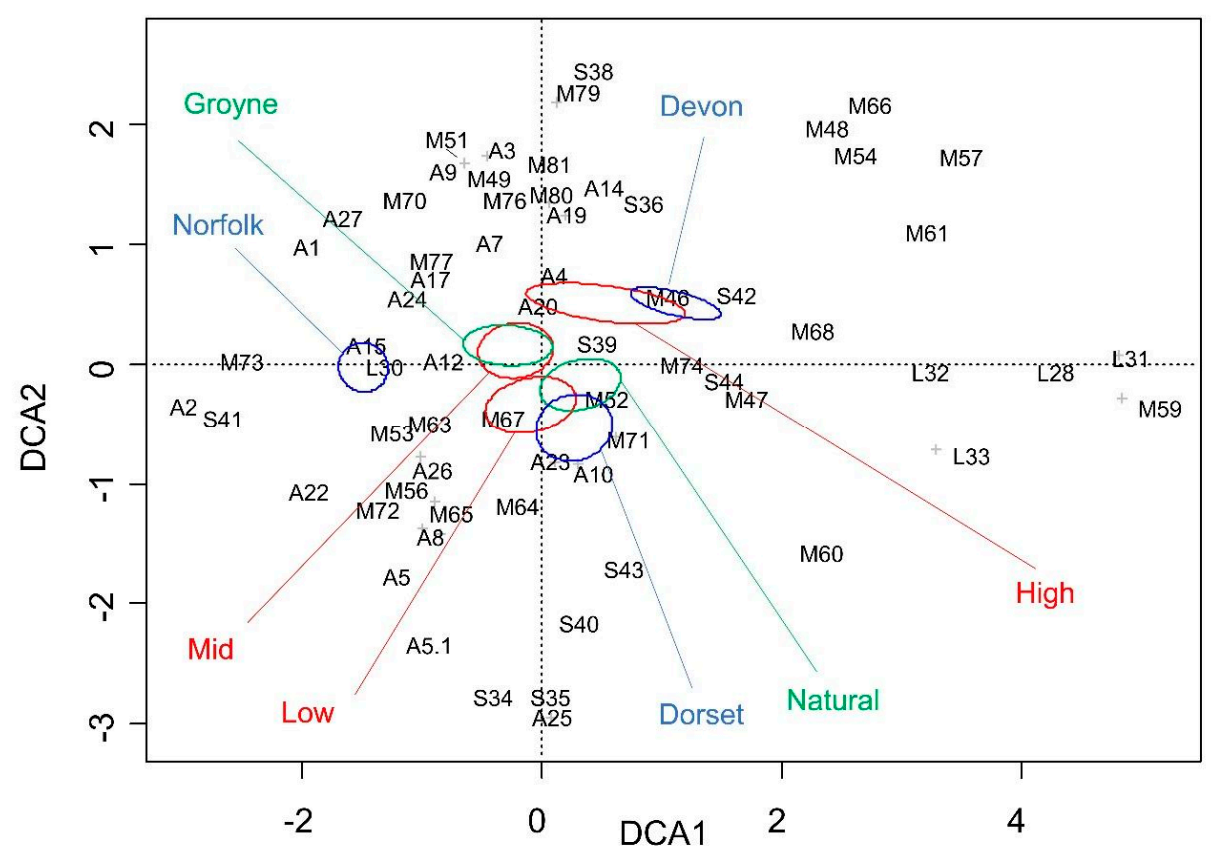

Figure 4. Ordination plot of detrended correspondence analysis (DCA) results on all species for rock and pool habitats combined. Labels represent species (see Supplementary Information 4 for a full list). Significant $(\alpha<0.01)$ environmental variables are represented as factor centroids with standard error ellipses. 


\subsection{Species Ranges}

We observed only two species beyond the ranges recorded for them in the sources we used: the lined top shell Phorcus lineatus at Sandbanks (only just beyond its recorded range [54]) and the small periwinkle Melarhaphe neritoides at Sheringham (closest recorded presence near Ipswich, nearly $140 \mathrm{~km}$ away [55]). Our dataset contained only one species not native to Great Britain: Austrominius modestus, identified at Stokes, Sidmouth and West Runton (Table 4). Gibson et al. [50] identified this species as present at all three sites, while Avant [56] recorded this species as only present at Sidmouth and Stokes. When present on groynes, A. modestus was at higher abundances than on the paired natural rocky shores (Table 4 ).

Table 4. Mean abundance of Austrominius modestus on open rock at different shore levels. The unit is the percentage of cover.

\begin{tabular}{cccccc}
\hline \multirow{2}{*}{ Site } & \multirow{2}{*}{ County } & \multirow{2}{*}{ Structure Type } & \multicolumn{3}{c}{ Shore Level } \\
\cline { 4 - 6 } & & & High & Mid & Low \\
\hline Sidmouth & Devon & Groyne & 5.9 & 49.8 & 60.8 \\
Stokes & Devon & Natural & 13.9 & 31.8 & 29.9 \\
West Runton & Norfolk & Natural & 0 & 2.3 & 0 \\
\hline
\end{tabular}

\section{Discussion}

The main aim of this investigation was to ascertain the extent to which rock-rubble groynes can support similar ecological communities to natural rocky shores, which several studies have identified as being under pressure [32]. Our findings suggest that although rock-rubble groynes support fewer species of intertidal macro-organisms than natural rocky shores (when measured using small quadrats across groyne-sized extents), these differences are not consistent across habitat (i.e., rock or pool) and tidal level (i.e., high, mid, low). On the exposed rock surfaces, the relatively small difference in species richness between the groynes and the natural rocky shores may reflect no more than a species-area effect over the entire ecosystem, i.e., the total area of rock-surface habitat is relatively small on the groynes compared with the natural rocky shores when viewed at a beach level. On the rock surfaces, the abundance of macro-organisms is, if anything, higher for the groynes. In the pools, it is much lower. Species that only occur on the groynes are associated with the higher abundance of mussels and barnacles (e.g., the Greenleaf worm) or they utilise the sandy habitat that is not present on the rocky shores (e.g., brown shrimp). Alternatively, the species found only on or predominantly on the natural shores appear to be those most sensitive to desiccation (e.g. Desmarestia aculeata). Much of the difference between structures appears to be due to the paucity of rock pools on the groynes, especially complex pools (Table 5).

Differences in the complexity of the intertidal zone, particularly in relation to water-retention capacity, may therefore explain some of the results. Natural rocky shores typically have higher complexity, with more microhabitats providing shelter from desiccation and other stresses [43] — for example groves, gullies and cracks, all of which can maintain moisture at low tide. In algae, higher rates of water loss speed up the decline of photosynthesis and respiration [57], and when desiccation past a critical water content occurs, irreversible damage results [58]. Retention of water is also vital for mollusc survival and maintenance [59]. Incorporating rock pool features on artificial structures has been shown to increase the diversity of intertidal taxa, sometimes by four- to nine-fold [24,60-62]. The structure of rock pools on groynes was relatively simple. The predominant formation of pools on groynes was where substrate had become saturated and water had built up against the rocks, with a few pools in the higher tidal level having been formed by chemical weathering. The simplistic structure of these pools meant only certain species (e.g., Palaemon serratus with anti-predatory mechanisms of immobility and cryptic appearance [63]) could survive there. 
Table 5. Mean numbers of rock pools in the sampling sections ( \pm 1 standard error).

\begin{tabular}{ccc}
\hline & Groynes & Natural \\
\hline High shore & \multicolumn{1}{c}{} \\
All counties & $\mathbf{0 . 9}$ & $\mathbf{9 . 7}$ \\
Devon & $1.0 \pm 1.0$ & $0.7 \pm 0.6$ \\
Dorset & $2.0 \pm 1.7$ & $7.3 \pm 1.2$ \\
Norfolk & $0.3 \pm 0.6$ & $18.7 \pm 7.6$ \\
Mid shore & & \\
All counties & $\mathbf{2 . 3}$ & $\mathbf{1 4 . 8}$ \\
Devon & $1.0 \pm 1.0$ & $6.7 \pm 1.5$ \\
Dorset & $3.3 \pm 0.6$ & $13.7 \pm 5.1$ \\
Norfolk & $3.0 \pm 1.0$ & $26.3 \pm 3.2$ \\
Low shore & & \\
All counties & 3.8 & $\mathbf{1 3 . 7}$ \\
Devon & $0.3 \pm 0.6$ & $8.7 \pm 2.5$ \\
Dorset & $5.0 \pm 1.0$ & $20.0 \pm 1.7$ \\
Norfolk & $4.7 \pm 0.6$ & $12.3 \pm 2.5$ \\
\hline
\end{tabular}

While clear delineations of communities exist across the tidal levels for rock and pool habitats combined (Figure 4), there was a difference between generalist species (e.g., P. serratus, Anemonia viridis) at the higher end of axis 2 and specialist species (e.g., Halichondria panicea, Adocia cinerea) at the lower end of axis 2 in the DCA. These results suggest that distinct communities of species that are sensitive to desiccation exist at all tidal levels, but currently the structure of rock pools on groynes only support generalist species. It should be noted that pool depth and perimeter were not measured within this study, following similar approaches used on groynes [21,23], and while precautions were made to minimise variations among pools (e.g., pools of similar size; grouping of quadrats), there is the possibility that differences between pools may be due to pool depth and complexity $[64,65]$. Thus, while our results identified lower biodiversity in rock pool habitats on groynes, there may be potential for artificial rock pool habitats to replicate those found on natural shores, and further research into which species benefit from rock pool presence, as well as which type of rock pools harbour the most species on groynes needs to be undertaken.

Furthermore, in times of low amplitude, a characteristic of the diurnal currents in the English Channel (in Dorset) causes the effects of the varying topography to become pronounced, causing shallow water harmonics which are responsible for a double-tide [66]. This means that there is a relatively long stand of high water, and for approximately 16 hours of the 24-h cycle, the water level is above the mid-water spring tide level [67]. Consequently, while Sandbanks may not be as complex as a natural shore, it retains water in other ways through this double-tide and the intertidal species are subject to reduced levels of desiccation, which could explain the higher biodiversity observed there (Figure 3, Supplementary Information 5). We felt it was important to include Sandbanks in our study due to the contrasting results found in previous research [21,23], but it should be noted that tidal regimes have a large impact on the ecological communities, and while pairing sites by geographic proximity removed some of this uncertainty, the tidal regime may be a compounding factor within the county variable implemented in the ANOVAs (Tables 1 and 2).

The higher algal abundance at Sandbanks may also be explained by the rock surface heterogeneity. Most seaweeds attach to the rock through a combination of etching, gripping or glue, and carbonate rocks tend to support such attachment more than other rock types $[68,69]$, and the physical and chemical substrate properties are known to affect organism adhesion and persistence [70]. The Sandbanks groynes are made of limestone, while the groynes at Sheringham and Sidmouth are made of syenite and granite, respectively (Table SI1). However, there was no significant difference in algal richness or abundance between structures in Devon, although there was a significantly higher abundance of sessile animals on the Sidmouth groynes. The relatively low algal abundance at Sheringham and Sidmouth may be due to the simpler structure of rock material. We paired sample sites based on proximity 
rather than rock type in order to address questions pertaining to the spread of geographic distributions and compare nearby biological assemblages. Therefore, we are unable to separate possible effects of structure type and rock type; however, our results (Tables 1 and 2, Figures 2 and 3) do suggest that features associated with the structure type may have a stronger influence than rock type alone. While geographic proximity was a key feature of our analysis, the distance between structures in Devon was approximately $100 \mathrm{~km}$. Stokes Beach is publicly-accessible and not characterised by steep cliff faces (as is typical in the region), and represented the closest suitable, safe and accessible rocky shore, rather than necessarily the closest in Euclidean space. Future research should aim to investigate the role of type in the biological assemblages of groynes, as well the conservation value of ensuring that rock type of artificial structures mimics nearby rocky shores (as a form of ecological engineering).

The higher abundance of sessile animals on rock-rubble groynes has important conservation implications. The dog whelk Nucella lapillus was recently included in the OSPAR List of threatened and/or declining species and habitats. We found that this species was more prevalent and abundant on the groynes where there was a higher abundance of sessile animals (e.g., mussels and barnacles), which make up a substantial part of $N$. lapillus' diet [71]. The simple structure of groynes provides refuge for many generalist species, which in turn provide trophic support to the wider ecosystem, resulting in clear communities of dog whelks and barnacles (Figure 4). We also found Pomatoschistus minutus on both natural shores and groynes. While the total abundance was higher on natural shores (Table 3), the presence of this species on groynes suggests that they have the potential to mimic natural shores and rock pools, yet currently do not support equivalent abundances. Interestingly, the DCA identified P. minutus within communities of Sea Oak Halidrys siliquosa and Corallina officinalis (Figure 4). H. siliquosa supports a range of invertebrate epifauna and epifloral (including red algae such as C. officinalis), suggesting that the trophic interactions among these species are vital for the presence of rare species. Moreover, the role of ecosystem engineers [72] in generating microhabitats that provide refuge by reducing the impact of abiotic stresses in coastal ecosystems is important for intertidal communities. The incorporation of biotic interactions in statistical models is a key research frontier in spatial ecology [73,74], and our results (Figure 4) suggest such interactions are key to determining representative communities on artificial structures. However, more research is needed to link the abiotic and biotic factors responsible for intertidal communities on artificial structures and highlight key ecosystem engineering designs that could be introduced to increase biodiversity during construction.

Austrominius modestus was the only species identified in our study that is not native to Great Britain. As such, we cannot sensibly comment on the proposition that artificial structures support a higher richness of non-indigenous taxa, beyond stating that this species was located on both structure types in Devon, but only on the natural shore in Norfolk-contradicting the proposition. We did find higher abundances on the groynes in Devon than on the nearby rocky shores (Table 4), which supports other studies that have found higher densities of $A$. modestus on artificial structures in the UK [75]. However, the indigenous barnacle species were also more abundant on groynes than natural rocky shores, so the non-indigenous species may not differ from the natives in this respect. Possible explanations for the increase in barnacle abundance on groynes could be a function of larval supply, availability of space (i.e., lack of microflora), rock type and post-settlement mortality [76,77], meaning future studies should aim to quantify the possible risk associated with such factors in quantifying non-indigenous taxa spread via artificial structures.

Furthermore, we only observed two native British species beyond their previously-recorded ranges: the lined top shell Phorcus lineatus at Sandbanks and the small periwinkle Melarhaphe neritoides at Sheringham. According to Crothers [78], P. lineatus has an Eastern limit around Kimmeridge bay (Figure 1), due to a combination of unsuitable winter temperature and, importantly, lack of suitable habitat to the East. According to Pizzolla [55], M. neritoides is absent between Ipswich (approx. $140 \mathrm{~km}$ Southeast of Sheringham) and Scarborough (approx. 400km North of Sheringham). Both species are considered highly-mobile [78,79], and their establishment on the groynes suggests that these artificial 
structures are providing alternative habitat for species that are limited by a lack of habitat rather than poor dispersal capacity. In sum, while rock-rubble groynes may provide non-indigenous species (whether defined nationally or internationally) with suitable habitat (along with indigenous species), we found no evidence that they enhance the dispersal of these species; more likely is that habitat availability is one of the most important factors limiting intertidal organism distributions [80].

We opted to delineate tidal heights based on the spring tidal levels rather than organism distribution limits for the aforementioned reasons. However, the double high tide at Sandbanks complicates this categorization. A continuous variable measuring distance from a specified point (e.g., the high spring tide mark) may have allowed for more flexibility in investigating the influence of tidal level on the ecological indicators; however, a simple distance metric would not account for variation in the distance and speed of tidal ranges. Discussion on the optimal method of measuring the seaward extent and tidal levels across different study areas remains a priority for studies investigating intertidal ecology. Similarly, we did not measure vertical height. While vertical height influences desiccation rates of species, the range of vertical elevation across tidal levels was quite consistent across study sites, and as such, we are confident that any possible artefacts introduced through the chosen methodology have not biased our results. Similarly, we controlled for aspect through surveying the 'sheltered' side of the structure; while aspect in the sense of compass direction can also influence photosynthetic rates of algae $[6,81,82]$, the predominant aspects of all groynes were East- and West-facing, minimising the influence of this in our study.

Finally, it is important to note that the age of an artificial structure will influence the ecological communities found. All groynes surveyed were of a similar age (Table SI1), so therefore, we are confident that cross-site error was minimised. However, this is an important consideration when discussing the ecosystem services provided by groynes, and particularly comparing with natural rocky shores, and when comparing groynes across different studies. Our results suggest different patterns to those identified by Pinn et al. [21] and Firth et al. [23]. The methodological differences among all three studies (e.g., deconstruction of the ecological indicators, direct statistical testing, unpaired sites) may be sufficient to explain contradictory results; however, it is important to consider the dynamic nature of ecosystems, and the unlikeliness of a balanced equilibrium. More developed groynes (e.g., older) may explain the higher species richness identified in pool habitats on artificial structures by Firth et al. [23], suggesting that these structures may develop complexity with time and support more diverse ecosystems. Similarly, older groynes offer greater opportunity for invasion than younger groynes simply by being around for longer. Therefore, investigating spatiotemporal trends in biodiversity on artificial structures in urban environments should now be a primary avenue of research, to better evaluate their potential as a conservation opportunity, with the data from this study available in Supplementary Information 2 to encourage such studies.

\section{Conclusions}

Rock-rubble groynes in urban environs have provided researchers and practitioners with a conservation dilemma. On the one hand, they can provide much-needed habitat for intertidal species that are decreasing in abundance, while on the other hand, by providing such habitat they may help non-indigenous species expand their ranges. Our results suggest that the rock surfaces of rock-rubble groynes do provide potential benefit for species for which this habitat is suitable, including species that are of conservation concern. We found similar diversity on rock surface habitats between structure types and found higher abundances of sessile animals on groynes. The rock pool habitat represents a key difference between the groynes and the natural rocky shores, with rock pools on groynes being smaller, fewer and less complex than on natural rocky shores. We identified clear communities of algae and endangered fish species (Figure 4) in pools, suggesting that rock pool creation can result in similar ecological communities on groynes, albeit at lower abundances. We also found very few non-native species on groynes, and those species were also found on corresponding natural rocky shores, offering no support for the notion that groynes pose a threat in terms of biological invasions 
(at least in the UK). While structure age and equilibrium in the ecosystem must be considered, the results of this study suggest that rock-rubble groynes have the potential to support under-pressure intertidal macro-organisms, particularly in urban environments, where the trend to replace natural shoreline with artificial structures is continuing.

Supplementary Materials: The following are available online at http://www.mdpi.com/2073-445X/9/5/131/s1: Supplementary Information 1: Details of the study sites. Supplementary Information 2: R Code. Supplementary Information 3: Species Data. Supplementary Information 4: Species name and code. Supplementary Information 5: Extra Analysis.

Author Contributions: Conceptualization, P.H. and R.F.; methodology, P.H. and R.F.; data curation, P.H.; formal analysis, P.H. and R.F.; writing-original draft preparation, P.H. and R.F. All authors have read and agreed to the published version of the manuscript.

Funding: This research received no external funding.

Acknowledgments: We would like to thank the reviewers and editors for their comments and suggestions. We would also like to thank our field assistants, Julia, Eddie, and Michael.

Conflicts of Interest: The authors declare no conflict of interest.

\section{References}

1. Walther, G.-R.; Post, E.; Convey, P.; Menzel, A.; Parmesan, C.; Beebee, T.J.C.; Fromentin, J.-M.; Hoegh-Guldberg, O.; Bairlein, F. Ecological responses to recent climate change. Nature 2002, 416, 389-395. [CrossRef]

2. Chen, I.-C.; Hill, J.K.; Ohlemüller, R.; Roy, D.B.; Thomas, C.D. Rapid Range Shifts of Species Associated with High Levels of Climate Warming. Science 2011, 333, 1024-1026. [CrossRef]

3. Pacifici, M.; Foden, W.B.; Visconti, P.; Watson, J.E.; Butchart, S.H.; Kovacs, K.M.; Scheffers, B.R.; Hole, D.G.; Martin, T.G.; Akçakaya, H.R.; et al. Assessing species vulnerability to climate change. Nat. Clim. Chang. 2015, 5, 215-224. [CrossRef]

4. Holloway, P.; Miller, J.A.; Gillings, S. Incorporating movement in species distribution models: How do simulations of dispersal affect the accuracy and uncertainty of projections? Int. J. Geogr. Inf. Sci. 2016, 30, 1-25. [CrossRef]

5. Crowe, T.; Thompson, R.C.; Bray, S.; Hawkins, S. Impacts of anthropogenic stress on rocky intertidal communities. J. Aquat. Ecosyst. Stress Recover. 2000, 7, 273-297. [CrossRef]

6. Harley, C.D.G.; Helmuth, B. Local- and regional-scale effects of wave exposure, thermal stress, and absolute versus effective shore level on patterns of intertidal zonation. Limnol. Oceanogr. 2003, 48, 1498-1508. [CrossRef]

7. Lees, F.; Baillie, M.; Gettinby, G.; Revie, C.W. The Efficacy of Emamectin Benzoate against infestations of Lepeoptheirus salmonis on Farmed Atlantic Salmon (Salmo salar L.) in Scotland, 2002-2006. PLoS ONE 2008, 3, e1549. [CrossRef] [PubMed]

8. Spencer, M.; Birchenough, S.N.R.; Mieszkowska, N.; Robinson, L.A.; Simpson, S.; Burrows, M.T.; Capasso, E.; Cleall-Harding, P.; Crummy, J.; Duck, C.; et al. Temporal change in UK marine communities: Trends or regime shifts? Mar. Ecol. 2011, 32, 10-24. [CrossRef]

9. Sorte, C.J.B.; Davidson, V.E.; Franklin, M.C.; Benes, K.M.; Doellman, M.M.; Etter, R.J.; Hannigan, R.; Lubchenco, J.; Menge, B.A. Long-term declines in an intertidal foundation species parallel shifts in community composition. Glob. Chang. Biol. 2016, 23, 341-352. [CrossRef] [PubMed]

10. Obst, M.; Vicario, S.; Lundin, K.; Berggren, M.; Karlsson, A.; Haines, R.; Williams, A.; Goble, C.; Mathew, C.; Güntsch, A. Marine long-term biodiversity assessment suggests loss of rare species in the Skagerrak and Kattegat region. Mar. Biodivers. 2017, 48, 2165-2176. [CrossRef]

11. Hillebrand, H.; Brey, T.; Gutt, J.; Hagen, W.; Metfies, K.; Meyer, B.; Lewandowska, A.M. Climate Change: Warming Impacts on Marine Biodiversity. In Handbook on Marine Environment Protection; Springer Science and Business Media LLC: Berlin, Germany, 2017; pp. 353-373.

12. Smale, D.A.; Wernberg, T.; Oliver, E.C.J.; Thomsen, M.; Harvey, B.P.; Straub, S.C.; Burrows, M.T.; Alexander, L.V.; Benthuysen, J.A.; Donat, M.G.; et al. Marine heatwaves threaten global biodiversity and the provision of ecosystem services. Nat. Clim. Chang. 2019, 9, 306-312. [CrossRef] 
13. Neumann, B.; Vafeidis, A.; Zimmermann, J.; Nicholls, R. Future Coastal Population Growth and Exposure to Sea-Level Rise and Coastal Flooding-A Global Assessment. PLoS ONE 2015, 10, e0118571. [CrossRef] [PubMed]

14. Seto, K.C.; Fragkias, M.; Güneralp, B.; Reilly, M.K. A Meta-Analysis of Global Urban Land Expansion. PLoS ONE 2011, 6, e23777. [CrossRef] [PubMed]

15. Browne, M.; Chapman, M. Mitigating against the loss of species by adding artificial intertidal pools to existing seawalls. Mar. Ecol. Prog. Ser. 2014, 497, 119-129. [CrossRef]

16. Bulleri, F.; Chapman, M.G. The introduction of coastal infrastructure as a driver of change in marine environments. J. Appl. Ecol. 2010, 47, 26-35. [CrossRef]

17. Nordstrom, K.F. Living with shore protection structures: A review. Estuar. Coast. Shelf Sci. 2014, 150, 11-23. [CrossRef]

18. Perkins, M.J.; Ng, T.P.; Dudgeon, D.; Bonebrake, T.C.; Leung, K.M. Conserving intertidal habitats: What is the potential of ecological engineering to mitigate impacts of coastal structures? Estuar. Coast. Shelf Sci. 2015, 167, 504-515. [CrossRef]

19. Chapman, M.; Bulleri, F. Intertidal seawalls-New features of landscape in intertidal environments. Landsc. Urban Plan. 2003, 62, 159-172. [CrossRef]

20. Moschella, P.; Abbiati, M.; Aberg, P.; Airoldi, L.; Anderson, J.; Bacchiocchi, F.; Bulleri, F.; Dinesen, G.; Frost, M.; Gacia, E.; et al. Low-crested coastal defence structures as artificial habitats for marine life: Using ecological criteria in design. Coast. Eng. 2005, 52, 1053-1071. [CrossRef]

21. Pinn, E.H.; Mitchell, K.; Corkill, J. The assemblages of groynes in relation to substratum age, aspect and microhabitat. Estuar. Coast. Shelf Sci. 2005, 62, 271-282. [CrossRef]

22. Lam, N.W.; Huang, R.; Chan, B.K. Variations in Intertidal assemblages and zonation patterns between vertical artificial seawalls and natural rocky shores: A case study from Victoria Harbour, Hong Kong. Zool. Stud. 2009, 48, 184-195.

23. Firth, L.B.; Thompson, R.C.; White, F.J.; Schofield, M.; Skov, M.W.; Hoggart, S.P.G.; Jackson, J.; Knights, A.M.; Hawkins, S.J. The importance of water-retaining features for biodiversity on artificial intertidal coastal defence structures. Divers. Distrib. 2013, 19, 1275-1283. [CrossRef]

24. Firth, L.B.; Thompson, R.C.; Bohn, K.; Abbiati, M.; Airoldi, L.; Bouma, T.; Bozzeda, F.; Ceccherelli, V.; Colangelo, M.; Evans, A.; et al. Between a rock and a hard place: Environmental and engineering considerations when designing coastal defence structures. Coast. Eng. 2014, 87, 122-135. [CrossRef]

25. Aguilera, M.A.; Broitman, B.R.; Thiel, M. Spatial variability in community composition on a granite breakwater versus natural rocky shores: Lack of microhabitats suppresses intertidal biodiversity. Mar. Pollut. Bull. 2014, 87, 257-268. [CrossRef] [PubMed]

26. Sanabria-Fernandez, J.A.; Lazzari, N.; Riera, R.; Becerro, M.A. Building up marine biodiversity loss: Artificial substrates hold lower number and abundance of low occupancy benthic and sessile species. Mar. Environ. Res. 2018, 140, 190-199. [CrossRef] [PubMed]

27. Bulleri, F.; Chapman, M.G.; Underwood, A.J. Intertidal assemblages on seawalls and vertical rocky shores in Sydney Harbour, Australia. Austral. Ecol. 2005, 30, 655-667. [CrossRef]

28. Bacchiocchi, F.; Airoldi, L. Distribution and dynamics of epibiota on hard structures for coastal protection. Estuar. Coast. Shelf Sci. 2003, 56, 1157-1166. [CrossRef]

29. Pister, B. Urban marine ecology in southern California: The ability of riprap structures to serve as rocky intertidal habitat. Mar. Biol. 2009, 156, 861-873. [CrossRef]

30. Chapman, M.G. Paucity of mobile species on constructed sea walls: Effects of urbanisation on biodiversity. Mar. Ecol. Prog. Ser. 2003, 264, 21-29. [CrossRef]

31. Clynick, B.G. Assemblages of fish associated with coastal marinas in north-western Italy. J. Mar. Biol. Assoc. U. K. 2006, 86, 847-852. [CrossRef]

32. Pinn, E.H.; Rodgers, M. The influence of visitors on intertidal biodiversity. J. Mar. Biol. Assoc. U. K. 2005, 85, 263-268. [CrossRef]

33. Bishop, M.J.; Mayer-Pinto, M.; Airoldi, L.; Firth, L.B.; Morris, R.L.; Loke, L.H.L.; Hawkins, S.; Naylor, L.; Coleman, R.A.; Chee, S.Y.; et al. Effects of ocean sprawl on ecological connectivity: Impacts and solutions. J. Exp. Mar. Biol. Ecol. 2017, 492, 7-30. [CrossRef]

34. Bulleri, F.; Airoldi, L. Artificial marine structures facilitate the spread of a non-indigenous green alga, Codium fragile spp tomentosoides, in the north Adriatic Sea. J. Appl. Ecol. 2005, 42, 1063-1072. [CrossRef] 
35. Airoldi, L.; Turon, X.; Perkol-Finkel, S.; Rius, M. Corridors for aliens but not for natives: Effects of marine urban sprawl at a regional scale. Divers. Distrib. 2015, 21, 755-768. [CrossRef]

36. Holloway, M.G.; Keough, M.J. An introduced polychaete affects recruitment and larval abundance of sessile invertebrates. Ecol. Appl. 2002, 12, 1803-1823. [CrossRef]

37. Bulleri, F.; Abbiati, M.; Airoldi, L. The colonization of artificial human-made structures by the invasive alga Codium fragile ssp. tomentosoides in the north Adriatic Sea (NE Mediterranean). Hydrobiologia 2006, 555, 263-269. [CrossRef]

38. Glasby, T.M.; Connell, S.D.; Holloway, M.G.; Hewitt, C. Nonindigenous biota on artificial structures: Could habitat creation facilitate biological invasions? Mar. Biol. 2006, 151, 887-895. [CrossRef]

39. Airoldi, L.; Bulleri, F. Anthropogenic Disturbance Can Determine the Magnitude of Opportunistic Species Responses on Marine Urban Infrastructures. PLoS ONE 2011, 6, e22985. [CrossRef]

40. Vaselli, S.; Bulleri, F.; Benedetti-Cecchi, L. Hard coastal-defence structures as habitats for native and exotic rocky-bottom species. Mar. Environ. Res. 2008, 66, 395-403. [CrossRef]

41. Halpern, B.S.; Walbridge, S.; Selkoe, K.A.; Kappel, C.V.; Micheli, F.; D’Agrosa, C.; Bruno, J.F.; Casey, K.; Ebert, C.; Fox, H.; et al. A Global Map of Human Impact on Marine Ecosystems. Science 2008, 319, 948-952. [CrossRef]

42. Hawkins, S.J.; Jones, H.D. Marine Field Course Guide: Rocky Shores; IMMEL Publishing: London, UK, 1992.

43. Lohrer, A.M.; Fukui, Y.; Wada, K.; Whitlatch, R.B. Structural complexity and vertical zonation of intertidal crabs, with focus on habitat requirements of the invasive Asian shore crab, Hemigrapsus sanguineus (de Haan). J. Exp. Mar. Biol. Ecol. 2000, 244, 203-217. [CrossRef]

44. Walker, S.J.; Schlacher, T.A.; Thompson, L.M. Habitat modification in a dynamic environment: The influence of a small artificial groyne on macrofaunal assemblages of a sandy beach. Estuar. Coast. Shelf Sci. 2008, 79, 24-34. [CrossRef]

45. Dyderski, M.K.; Jagodziński, A.M. Low impact of disturbance on ecological success of invasive tree and shrub species in temperate forests. Plant Ecol. 2018, 219, 1369-1380. [CrossRef]

46. Oksanen, J.; Blanchet, F.G.; Friendly, M.; Kindt, R.; Legendre, P.; McGlinn, D.; Minchin, P.R.; O’Hara, R.B.; Simpson, G.L.; Solymos, P.; et al. Vegan: Community Ecology Package; R Package version 2.5-5; R Core Team: Vienna, Austria, 2019. Available online: https://CRAN.R-project.org/package=vegan (accessed on 30 June 2019).

47. Ter Braak, C.; Smilauer, P. Topics in constrained and unconstrained ordination. Plant Ecol. 2014, 216, $683-696$. [CrossRef]

48. Palmer, M.W. Putting Things in Even Better Order: The Advantages of Canonical Correspondence Analysis. Ecology 1993, 74, 2215-2230. [CrossRef]

49. R Development Core Team. R: A Language and Environment for Statistical Computing; R Foundation for Statistical Computing: Vienna, Austria, 2011; ISBN 3-900051-07-0. Available online: http://www.R-project.org/ (accessed on 19 August 2011).

50. Gibson, R.; Hextall, B.; Rogers, A. Photographic Guide to the Sea and Shore Life of Britain and North-West Europe; Oxford University Press: New York, NY, USA, 2001.

51. MarLIN (Marine Life Information Network). Marine Life Information Network; Marine Biological Association of the United Kingdom: Plymouth, UK, 2016. Available online: www.marlin.ac.uk (accessed on 1 January 2009).

52. Connor, D.W.; Allen, J.H.; Golding, N.; Howell, K.L.; Lieberknecht, L.M.; Northern, K.O.; Reker, J.B. The Marine Habitat Classification for Britain and Ireland; Version 04.05; JNCC: Peterborough, UK, 2004.

53. Werner, A. Lichen Growth Rates for the Northwest Coast of Spitsbergen, Svalbard. Arct. Alp. Res. 1990, 22, 129. [CrossRef]

54. Mieszkowska, N. Osilinus lineatus. Thick Top Shell. Marine Life Information Network: Biology and Sensitivity Key Information Sub-Programme; Marine Biological Association of the United Kingdom: Plymouth, UK, 2008. Available online: http://www.marlin.ac.uk/speciesfullreview.php?speciesID=3990 (accessed on 30 March 2012).

55. Pizzolla, P. Melarhaphe neritoides. Small periwinkle. Marine Life Information Network: Biology and Sensitivity Key Information Sub-Programme; Marine Biological Association of the United Kingdom: Plymouth, UK, 2007. Available online: http://www.marlin.ac.uk/speciesinformation.php?speciesID=3785 (accessed on 30 March 2012). 
56. Avant, P. Elminius modestus. An Acorn Barnacle. Marine Life Information Network: Biology and Sensitivity Key Information Sub-Programme; Marine Biological Association of the United Kingdom: Plymouth, UK, 2007. Available online: http://www.marlin.ac.uk/speciesinformation.php?speciesID=3252 (accessed on 30 March 2012).

57. Ji, Y.; Tanaka, J. Effect of desiccation on the photosynthesis of seaweeds from the intertidal zone in Honshu, Japan. Phycol. Res. 2002, 50, 145-153. [CrossRef]

58. Baugh, T.M.; Yarish, C.; Kirkman, H. Seaweeds: Their Environment, Biogeography, and Ecophysiology. Revised Translation of (Meersbotanik: Verbreitung, ökophysiologie und Nutzung der Marinen Makroalgen), K. Lüning (1985). Estuaries 1992, 15, 255. [CrossRef]

59. Moreira, J.; Chapman, M.; Underwood, A. Maintenance of chitons on seawalls using crevices on sandstone blocks as habitat in Sydney Harbour, Australia. J. Exp. Mar. Biol. Ecol. 2007, 347, 134-143. [CrossRef]

60. Chapman, M.G.; Blockley, D.J. Engineering novel habitats on urban infrastructure to increase intertidal biodiversity. Oecologia 2009, 161, 625-635. [CrossRef]

61. Firth, L.B.; Browne, K.A.; Knights, A.M.; Hawkins, S.J.; Nash, R. Eco-engineered rock pools: A concrete solution to biodiversity loss and urban sprawl in the marine environment. Environ. Res. Lett. 2016, 11, 94015. [CrossRef]

62. Strain, E.M.A.; Olabarria, C.; Mayer-Pinto, M.; Cumbo, V.; Morris, R.L.; Bugnot, A.; Dafforn, K.; Heery, E.; Firth, L.B.; Brooks, P.; et al. Eco-engineering urban infrastructure for marine and coastal biodiversity: Which interventions have the greatest ecological benefit? J. Appl. Ecol. 2017, 55, 426-441. [CrossRef]

63. Evans, S.; Finnie, M.; Manica, A. Shoaling preferences in decapod crustacea. Anim. Behav. 2007, 74, 1691-1696. [CrossRef]

64. Martins, G.M.; Hawkins, S.; Thompson, R.C.; Jenkins, S.R. Community structure and functioning in intertidal rock pools: Effects of pool size and shore height at different successional stages. Mar. Ecol. Prog. Ser. 2007, 329, 43-55. [CrossRef]

65. Moksnes, P.O.; Pihl, L.; van Montfrans, J. Predation on postlarvae and juveniles of the shorecrab Carcinus maenus: Importance of shelter, size, and cannibalism. Mar. Ecol. Prog. Ser. 1998, 166, 211-225. [CrossRef]

66. Pugh, D.T. Changing Sea Levels: Effects of Tide, Weather, and Climate; Cambridge University Press: New York, NY, USA, 2004.

67. Humphreys, J. Salinity and Tides in Poole Harbour: Estuary or Lagoon? In The Ecology of Poole Harbour; Humphreys, J., May, V., Eds.; Elsevier: Oxford, UK, 2005.

68. Bromley, R.G.; Heinberg, C. Attachment strategies of organisms on hard substrates: A palaeontological view. Palaeogeogr. Palaeoclim. Palaeoecol. 2006, 232, 429-453. [CrossRef]

69. Coombes, M.A.; La Marca, E.C.; Naylor, L.A.; Thompson, R.C. Getting into the goove: Opportunities to enhance the ecological value of hard coastal infrastructure using fine-scale surface textures. Ecol. Eng. 2015, 77, 314-323. [CrossRef]

70. Fletcher, R.L.; Callow, M.E. The settlement, attachment and establishment of marine algal spores. Br. Phycol. J. 1992, 27, 303-329. [CrossRef]

71. Underwood, A.; Chapman, M.; Crowe, T. Identifying and understanding ecological preferences for habitat or prey. J. Exp. Mar. Biol. Ecol. 2004, 300, 161-187. [CrossRef]

72. Jones, C.; Lawton, J.H.; Shachak, M. Organisms as Ecosystem Engineers. Oikos 1994, 69, 373. [CrossRef]

73. Peterson, A.T.; Soberón, J.; Ramsey, J.; Osorio-Olvera, L. Co-occurrence Networks do not Support Identification of Biotic Interactions. Biodivers. Inform. 2020, 15, 1-10. [CrossRef]

74. Dormann, C.F.; Bobrowski, M.; Dehling, D.M.; Harris, D.J.; Hartig, F.; Lischke, H.; Moretti, M.D.; Pagel, J.; Pinkert, S.; Schleuning, M.; et al. Biotic interactions in species distribution modelling: 10 questions to guide interpretation and avoid false conclusions. Glob. Ecol. Biogeogr. 2018, 27, 1004-1016. [CrossRef]

75. Bracewell, S.A.; Robinson, L.A.; Firth, L.B.; Knights, A.M. Predicting Free-Space Occupancy on Novel Artificial Structures by an Invasive Intertidal Barnacle Using a Removal Experiment. PLoS ONE 2013, 8, e74457. [CrossRef] [PubMed]

76. Maki, J.S.; Ding, L.; Stokes, J.; Kavouras, J.H.; Rittschof, D. Substratum/bacterial interactions and larval attachment: Films and exopolysaccharides ofHalomonas marina (ATCC 25374) and their effect on barnacle cyprid larvae, Balanus amphitriteDarwin. Biofouling 2000, 16, 159-170. [CrossRef]

77. Miron, G.; Boudrea, B.; Bourget, E. Intertidal barnacle distribution:a case study using multiple working hypotheses. Mar. Ecol. Prog. Ser. 1999, 189, 205-219. [CrossRef] 
78. Crothers, J.H. Common topshells: An introduction to the biology of Osilinus lineatus with notes on other species in the genus. Field Stud. 2001, 10, 115-160.

79. Riel Patrick, V.; Breugelmans, K.; De Wolf, H.; Mikhailova, N.; Backeljau, T. Analysis of mitochondrial DNA variation via PCR-SSCP revels micro- and macrogeographic genetic heterogeneity in the planktonic developing periwinkle, Melaraphe neriotoides (Caenogastropoda, Littorinidae). Vlis Spec. Publ. 2004, $17,76$.

80. Wang, W.; Wang, J.; Choi, F.M.P.; Ding, P.; Li, X.; Han, G.; Ding, M.; Guo, M.; Huang, X.; Duan, W.; et al. Global warming and artificial shorelines reshape seashore biogeography. Glob. Ecol. Biogeogr. 2019, 29, 220-231. [CrossRef]

81. Chu, F.J.; Seaward, M.R.D.; Hodgkiss, I.J. Effects of Wave Exposure and Aspect on Hong Kong Supralittoral Lichens. Lichenologist 2000, 32, 155-170. [CrossRef]

82. Firth, L.B.; White, F.J.; Schofield, M.; Hanley, M.E.; Burrows, M.T.; Thompson, R.C.; Skov, M.W.; Evans, A.; Moore, P.J.; Hawkins, S.J. Facing the future: The importance of substratum features for ecological engineering of artificial habitats in the rocky intertidal. Mar. Freshw. Res. 2016, 67, 131. [CrossRef]

(C) 2020 by the authors. Licensee MDPI, Basel, Switzerland. This article is an open access article distributed under the terms and conditions of the Creative Commons Attribution (CC BY) license (http://creativecommons.org/licenses/by/4.0/). 